\title{
Cellular Mechanisms in the Protection against Infection by Listeria monocytogenes in Mice
}

\author{
By K. TAKEYA, S. SHIMOTORI, T. TANIGUCHI AND K. NOMOTO \\ Department of Microbiology, Kyushu University, School of Medicine, \\ Fukuoka, 8I 2 Japan
}

(Received 23 December 1976)

\begin{abstract}
SUMMAR Y
Listeria monocytogenes, in doses of $2.0 \times 10^{3}$ to $3.0 \times 10^{3}$ viable organisms, was injected into athymic nude mice, irradiated mice and mice treated with reticuloendothelial system-blocking agents. Viable counts on liver and spleen homogenates were made at intervals after infection. In both nude mice (nu/nu) and normal littermates $(\mathrm{nu} /+)$ of BALB/c background, the bacteria grew rapidly for $24 \mathrm{~h}$ but increased only slowly thereafter, to reach a plateau of about $10^{5}$ per organ at $72 \mathrm{~h}$. In nu/ + mice, the number of viable bacteria began to decrease after 6 to 9 days, with complete elimination by day I 2 . In nude mice, the number of Listeria remained at a stable level of approximately $10^{5}$ per organ during the observation period of $2 \mathrm{I}$ days. In lethally irradiated $\mathrm{nu} /+$ mice, bacteria grew progressively and extensively to reach $10^{7}$ per spleen and $10^{9}$ per liver by $72 \mathrm{~h}$. Bacterial growth during the first $72 \mathrm{~h}$ was markedly enhanced by treatment with carbon particles, dextran sulphate 500 or silica. These enhancing effects were also observed in nude mice and in $\mathrm{AKR}, \mathrm{C}_{3} \mathrm{H} / \mathrm{He}$ and $\mathrm{C}_{57} \mathrm{BL} / 6$ animals. We conclude that both non-immune phagocytes and $\mathrm{T}$ cell-dependent mechanisms contribute to the resistance of mice to Listeria infection.
\end{abstract}

\section{INTRODUCTION}

Protection against Listeria monocytogenes has been reported to depend primarily on macrophages which are activated specifically or non-specifically by sensitized lymphocytes. Activated macrophages with antilisterial activity were generated by immunization not only with L. monocytogenes, but also with Brucella (Mackaness, 1964), Mycobacterium bovis (BCG) (Mackaness, 1964) or Toxoplasma (Krahenbuhl \& Remington, 197I). Furthermore, macrophages activated by listeria infection also inhibit intracellular growth of Salmonella typhimurium (Blanden, Mackaness \& Collins, 1966) and Candida albicans (Marra \& Balish, 1974). Thymus-derived (T) lymphocytes are required for activation of macrophages both in vivo and in vitro (Lane \& Unanue, 1972; North, I973 $a$; Cole, 1975). However, protection against these infections depends not only on $\mathrm{T}$ cell-mediated immunity, but also on the normal antimicrobial activity of phagocytes, including non-immune macrophages and neutrophils. Most of the investigations cited above were performed under conditions where both innate and induced immunity mechanisms might operate simultaneously. This study was designed to analyse the contribution of each of these elements to the elimination of L. monocytogenes. Thus bacterial growth has been monitored in athymic nude mice and in mice treated with irradiation and with reticuloendothelial system-blocking agents. 


\section{METHODS}

Animals. Athymic nude mice (nu/nu) of BALB/c background and their normal littermates $(\mathrm{nu} /+)$ were obtained from the Central Laboratory for Experimental Animals, Tokyo. They were raised in specific pathogen-free conditions and maintained in our laboratory in clean but not germ-free surroundings. Pellets, drinking water and bedding were sterilized in an autoclave and cages were covered with filter caps to minimize microbial contamination. Inbred mice of $\mathrm{C}_{3} \mathrm{H} / \mathrm{He}, \mathrm{AKR}$ and $\mathrm{C}_{57} \mathrm{BL} / 6$ strains were obtained from the Breeding Unit of Kyushu University, School of Medicine. They were raised and maintained in conventional conditions. Eight-week-old mice were used for experiments.

Micro-organism. Listeria monocytogenes (EGD) was kindly donated by Dr Ishibashi, Research Institute for Diseases of the Chest, Kyushu University, School of Medicine. The bacteria were maintained by serial passage in outbred $\mathrm{CF}_{1}$ mice. Fresh isolates were obtained from infected spleens, grown once on Tryptic Soy Agar medium (Difco) and used for infection.

Determination of bacterial growth in organs. Mice were inoculated intravenously with $2 \times 10^{3}$ to $3 \times 10^{3}$ viable bacteria in saline. At various times after infection, they were bled by cutting the femoral artery, and the spleen and liver were removed. Individual organs were homogenized separately in $10 \mathrm{ml}$ phosphate-buffered saline (PBS) with Teflon homogenizers. The homogenized suspensions were diluted serially Io-fold with PBS and $0.1 \mathrm{ml}$ of each dilution was spread on Tryptic Soy Agar. Three plates were prepared for each dilution of each specimen. Colonies were counted after incubation for $20 \mathrm{~h}$ at $37^{\circ} \mathrm{C}$.

$X$-irradiation. Mice were exposed to $900 \mathrm{R}$ of whole body $\mathrm{X}$-irradiation and infected 3 days later. The radiation was delivered from a Shimadzu $250 \mathrm{kV}$ machine operating at $200 \mathrm{kV}$ with $\mathrm{I} \mathrm{mm} \mathrm{Cu}$ and I $\mathrm{mm} \mathrm{Al}$ filtration at $100 \mathrm{~cm}$ from the target focus.

Blockade of the reticuloendothelial system. Carbon was administered according to Fisher (1966), but with minor modifications. Carbon particles (CI I/ I 43 Ia, Günther, Wagner) were suspended at $25 \mathrm{mg} \mathrm{ml}^{-1}$ in saline containing I \% gelatin, and $0.2 \mathrm{ml}$ was injected intravenously on days $-r$ and $o$, and intraperitoneally on day $I$ (with respect to infection). Dextran sulphate 500 (DS-500, mol. wt 500000; Pharmacia) was dissolved in $0.15 \mathrm{M}-\mathrm{NaCl}$ at $5 \mathrm{mg} \mathrm{ml}^{-1}$ and a dose of $50 \mathrm{mg} \mathrm{kg}^{-1}$ was given in each injection, according to Hahn (1974). Doses were administered once on day $-\mathrm{I}$ or twice on days $-\mathrm{I}$ and 0 . Silica ( $2 \mu \mathrm{m}$ average diam.) was suspended at $50 \mathrm{mg} \mathrm{ml}^{-1}$ in saline according to Zisman, Hirsch \& Allison (I970), and I ml was injected intraperitoneally three times on days $-\mathrm{I}, \mathrm{O}$ and I. All of the above mice were inoculated with L. monocytogenes on day o.

\section{RESULTS}

\section{Growth of bacteria in nude mice}

A suspension containing $2.6 \times 10^{3} \mathrm{~L}$. monocytogenes was injected intravenously into $\mathrm{nu} / \mathrm{nu}$ and $\mathrm{nu} /+$ mice on day $\mathrm{o}$ and live bacteria in the spleen and liver were counted up to $2 \mathrm{I}$ days later. Three animals were taken from each group at each time. Numbers of live bacteria in the liver and spleen were slightly higher in nu/ + than in nu/nu mice on day 3 (Fig. I). However, they had begun to disappear by day 6 and day 9 , respectively, from the spleen and liver of $\mathrm{nu} /+$ mice and were eliminated completely by day I2. On the other hand, approximately $10^{5}$ live bacteria were detected in both organs of $\mathrm{nu} / \mathrm{nu}$ mice during the whole observation period of 21 days. 


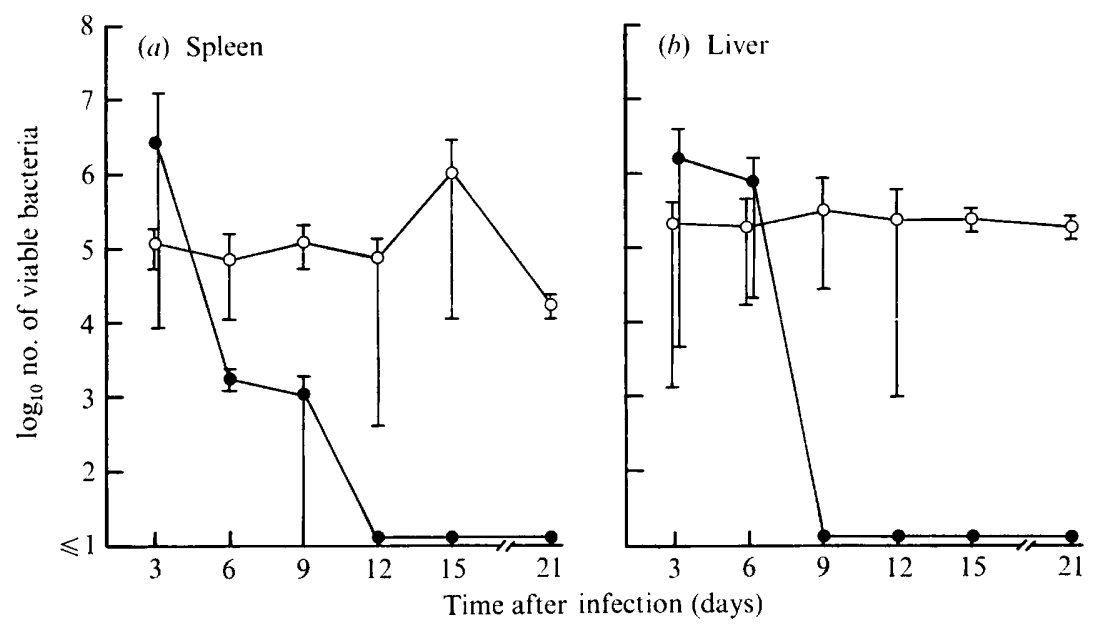

Fig. I. Growth of $L$. monocytogenes after an intravenous incculation of $2.6 \times 10^{3}$ live bacteria into nude mice $(O)$ and normal littermates $(\bullet)$. Each point represents an average per organ and bars represent ranges.

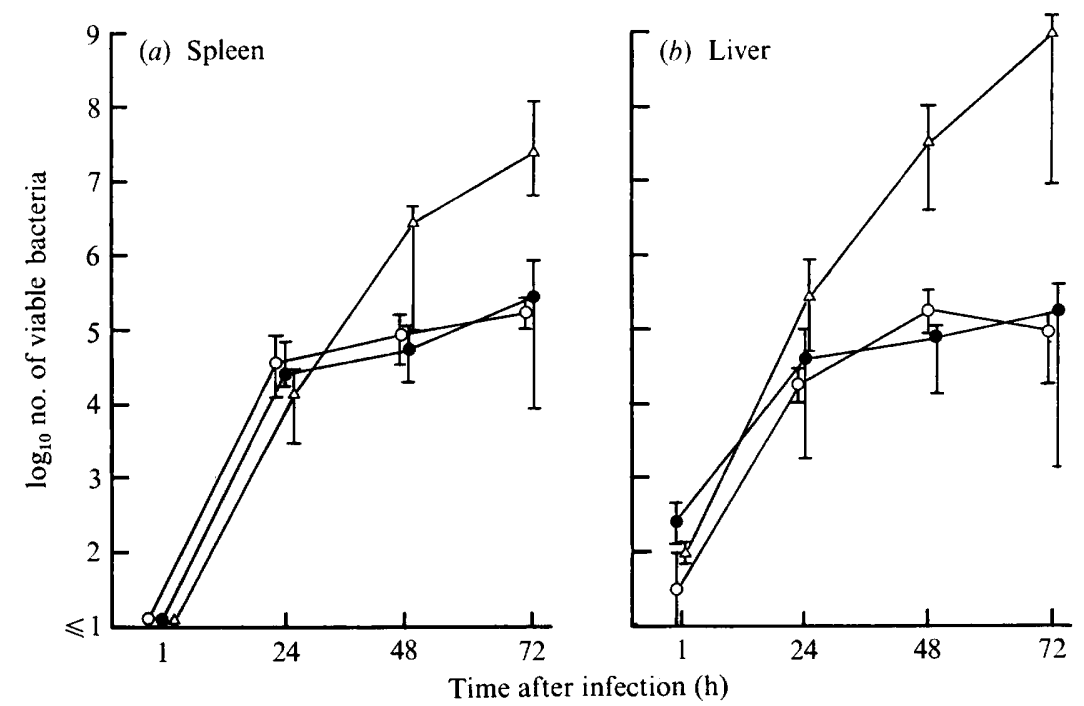

Fig. 2. Growth of L. monocytogenes after an intravenous inoculation of $2.0 \times 10^{3}$ live bacteria into nude mice $(O)$, normal littermates $(\bullet)$ and irradiated littermates $(\triangle)$. Each point represents an average per organ and bars represent ranges.

\section{Early growth of bacteria in irradiated mice}

A suspension containing $2 \cdot 0 \times \mathrm{IO}^{3}$ L. monocytogenes was injected intravenously into nu/nu, $\mathrm{nu} /+$ and irradiated $\mathrm{nu} /+$ mice on day $\mathrm{o}$. Live bacteria in the spleens and livers from three mice of each group were counted I, 24, 48 and $72 \mathrm{~h}$ later. In the spleens from mice of all three groups, few live bacteria were detected I h after inoculation (Fig. $2 a$ ), but numbers increased rapidly to reach over $\mathrm{IO}^{4}$ per spleen by $24 \mathrm{~h}$. Thereafter numbers of bacteria increased only slightly in nu/nu and nu/ + mice, while the count in irradiated nu/ + mice increased progressively to reach over $10^{7}$ by $72 \mathrm{~h}$. Similar patterns of bacterial growth were observed in the 


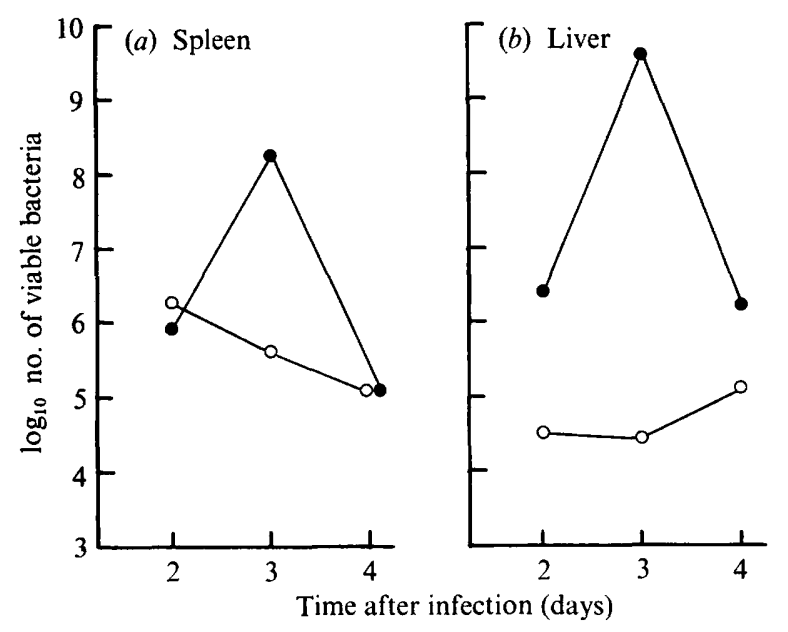

Fig. 3. Growth of $L$. monocytogenes after an intravenous inoculation of $3.0 \times \mathrm{ro}^{3}$ live bacteria into normal $(\mathrm{O})$ and DS-500-treated $(\bullet) \mathrm{C}_{3} \mathrm{H} / \mathrm{He}$ mice. Each point represents an average of five animals.
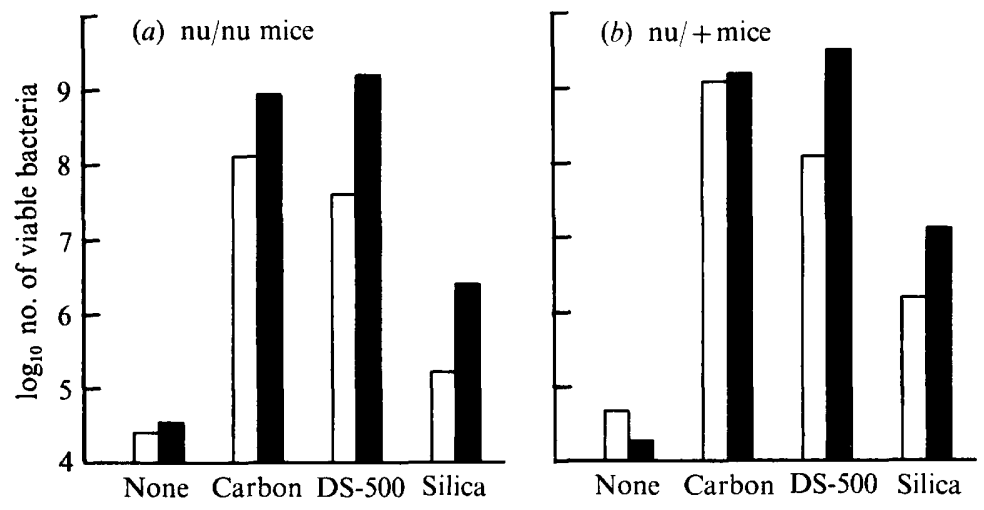

Fig. 4. Growth of $L$. monocytogenes at 3 days after an intravenous inoculation of $3.0 \times 10^{3}$ live bacteria into nude mice $(\mathrm{nu} / \mathrm{nu})$ and littermates $(\mathrm{nu} /+)$ which had been treated with carbon, DS-500 or silica. Open and closed columns represent the numbers of bacteria in the spleen and liver, respectively. Each column represents an average of five animals.

livers from mice of these groups, although the total numbers of live bacteria per organ were higher than in the corresponding spleens (Fig. $2 b$ ).

\section{Effect of reticuloendothelial blockade}

To find out the effect of reticuloendothelial blockade, DS-500 was injected intraperitoneally into $\mathrm{C}_{3} \mathrm{H} / \mathrm{He}$ mice on day $-\mathrm{I}$ and $3.0 \times \mathrm{I}^{3} \mathrm{~L}$. monocytogenes was injected intravenously on day 0 . Live bacteria were counted in the spleen and liver 2, 3 and 4 days later. Pretreatment with DS-500 enhanced growth in the spleen but this was only detected on day 3 (Fig. $3 a$ ). Enhancement of bacterial growth in the liver was most prominent on day 3 , although present to a lesser extent on days 2 and 4 (Fig. 3 b). To explore this further, the effects of blocking agents administered 3 days after infection were examined.

A suspension containing $3.0 \times 10^{3}$ L. monocytogenes was injected intravenously into four groups of $\mathrm{nu} / \mathrm{nu}$ and $\mathrm{nu} /+$ mice and bacteria in the spleen and liver were counted 3 days 


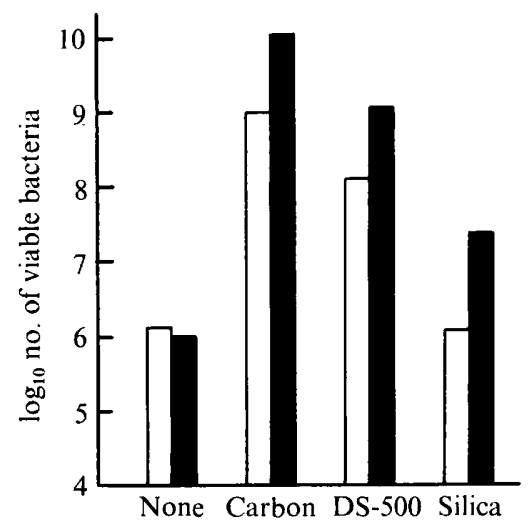

Fig. 5. Growth of L. monocytogenes at 3 days after an intravenous inoculation of $3.0 \times 10^{3}$ live bacteria into AKR mice which had been treated with carbon, DS-500 or silica. Open and closed columns represent the numbers of bacteria in the spleen and liver, respectively. Each column represents an average of five animals.

later. Each group consisted of five animals. Bacterial growth in both $\mathrm{nu} / \mathrm{nu}$ and $\mathrm{nu} /+$ mice was markedly enhanced by injection of carbon or DS-500 (Fig. 4). The numbers of bacteria in mice treated with such agents reached $10^{8}$ to $10^{9}$ in the spleen and $10^{9}$ to $10^{10}$ in the liver, while in non-treated $\mathrm{nu} / \mathrm{nu}$ and $\mathrm{nu} /+$ mice there were less than $10^{5}$ in both organs. Bacterial growth was also enhanced by treatment with silica, although to a lesser extent than by treatment with the other two agents. No difference in the degree of enhancement was detected between $\mathrm{nu} / \mathrm{nu}$ and $\mathrm{nu} /+$ mice.

The effects of the blocking agents on bacterial growth were also investigated in conventional $\mathrm{AKR}, \mathrm{C}_{3} \mathrm{H} / \mathrm{He}$ and $\mathrm{C}_{57} \mathrm{BL} / 6$ mice. When no blocking agent was given, the number of live bacteria per organ was greatest in $\mathrm{AKR}$, smallest in $\mathrm{C} 57 \mathrm{BL} / 6$ and intermediate in $\mathrm{C}_{3} \mathrm{H} / \mathrm{He}$ mice. Bacterial growth in the spleen and liver of AKR mice was enhanced markedly by carbon and DS-500 (Fig. 5). Treatment with silica slightly enhanced bacterial growth in the liver but not in the spleen. Similar patterns of enhanced bacterial growth were observed in $\mathrm{C}_{3} \mathrm{H} / \mathrm{He}$ and $\mathrm{C}_{57} \mathrm{BL} / 6$ mice, although the degree of enhancement varied slightly among the different combinations of host strains and blocking agents.

\section{DISCUSSION}

Protection against some kinds of micro-organisms depends on T cell-mediated immunity. Susceptibilities to such micro-organisms have been thought to increase in hosts with depressed functions of T lymphocytes. Increased susceptibilities of nude mice to experimental infections with L. monocytogenes (Emmerling, Finger \& Bockemühl, I975), M. bovis (BCG) (Sher et al., I975; Takeya et al., 1977), Babesia microti and Plasmodium berghei yoelii (Clark \& Allison, 1974) have been reported. According to Emmerling et al. (1975), viable organisms of L. monocytogenes were eliminated from the spleen of normal littermates in the typical course of an experimental infection, but were retained persistently in nude mice from an initial stage to a late stage of infection. We have confirmed their results (see Fig. I). According to North ( $1973 b)$, antilisteria immunity was not impaired in mice that had been thymectomized, irradiated and reconstituted with bone marrow cells (THXB mice), but their capacity to develop antituberculous immunity was greatly reduced. This observation is explained in terms of a residual $\mathrm{T}$ cell population in THXB mice which is large enough to 
generate antilisteria, but not antituberculous immunity. Thus, nude mice may have more depressed functions of T lymphocytes than THXB mice. Studies of nude mice may provide a new method for analysing the contribution of $\mathrm{T}$ cell-mediated immunity to the protection against at least some micro-organisms, although $\theta$-positive cells still exist in nude mice (Loor \& Roelants, 1974) and they increase in number in nude mice infected with mouse hepatitis virus (Scheid, Goldstein \& Boyse, 1975).

We expected to find a fulminating course of infection with $L$. monocytogenes in nude mice, since resistance to such organisms was generally considered to depend largely on $\mathrm{T}$ cellmediated immunity. However, nude mice showed a persistent form of infection rather than a fulminating course. The contribution of mechanisms other than $\mathrm{T}$ cell-mediated immunity has to be taken into account to understand the resistance to L. monocytogenes as a whole. Contribution of cells other than T lymphocytes was suggested by McGregor, Hahn \& Mackaness (1973). They found that thymectomized, irradiated rats rapidly regained the capacity to defend themselves from a primary infection with $L_{r}$ monocytogenes, when given syngeneic bone marrow cells. Such a resistance could be transferred with thoracic duct cells or peritoneal exudate cells, although the efficiency was not so good. In their system, the contribution of $\mathrm{T}$ lymphocytes to the recovery of the resistance may be small, if any.

Possible explanations of the resistance described above are protection by phagocytes, including non-immune macrophages and neutrophils, and protection by humoral immunity. A fulminating bacterial growth at an early stage of infection may be suppressed by the mechanism(s) which is present in nude mice and sensitive to lethal irradiation. There is some doubt about the radiosensitivity of fixed macrophages. The capacity to engulf carbon particles has been reported to be highly radioresistant (see Nelson, 1969). However, the capacity to digest engulfed chicken erythrocytes or Candida cells was reported to be radiosensitive (Donaldson et al., 1956). The enhanced bacterial growth within $72 \mathrm{~h}$ after infection in lethally irradiated mice may be ascribed to the depletion of the capacity of macrophages to digest bacterial cells, although such an experiment is not conclusive.

DS-500, a blocking agent of the reticuloendothelial system, enhanced bacterial growth within 3 days after infection with Listeria, as reported by Hahn (1974). Carbon particles enhanced bacterial growth to almost the same extent as DS-500. Bacterial growth was also enhanced by silica, although this was less effective than DS-500 or carbon particles. Enhancement was detected in all $\mathrm{nu} / \mathrm{nu}, \mathrm{nu} /+, \mathrm{AKR}, \mathrm{C}_{57} \mathrm{BL} / 6$ and $\mathrm{C}_{3} \mathrm{H} / \mathrm{He}$ mice and may be ascribed to the depletion of non-immune phagocytes. It is not due to the suppression of immune macrophages which may be generated in the presence of antigen-specific sensitized lymphocytes.

Three days after infection, the numbers of live bacteria in the spleen and liver were slightly lower in nude mice than in normal littermates, an observation that may be attributed to a higher level of macrophage activation in nude mice. At least two explanations could account for this phenomenon, as suggested by Meltzer (1976). First, macrophage functions may be augmented in the presence of a deficient homeostatic $T$ cell effect. Secondly, macrophages may be activated more readily in nude mice by subclinical infection and by interactions with natural bacterial flora and bacterial by-products. The latter explanation is more likely since Meltzer did not detect augmented macrophage activation in germ-free nude mice.

Thus, a defence mechanism by non-immune phagocytes appears to play an important role in resistance to $L$. monocytogenes, especially at an early stage after infection. Fulminating bacterial growth may be suppressed by such a mechanism before immunological mechanisms are raised several days after infection. Activated immune macrophages appear to be required for complete elimination of bacteria at a late stage of infection. 
This study was supported by Grants-in-Aid for Cancer Research and Scientific Research from the Ministry of Education, Science and Culture, Japan.

\section{REFERENCES}

Blanden, R. V., Mackaness, G. B. \& Collins, F. M. (I966). Mechanisms of acquired resistance in mouse typhoid. Journal of Experimental Medicine 124, 585-600.

Clark, I. A. \& Allison, A. C. (1974). Babesia microti and Plasmodium berghei yoelii infections in nude mice. Nature, London 252, 328-329.

CoLe, P. (1975). Activation of mouse peritoneal cells to kill Listeria monocytogenes by T-lymphocyte products. Infection and Immunity 12, 36-41.

Donaldson, D. M., Marcus, S., Gyi, K. K. \& Perkins, E. H. (I956). The influence of immunization and total body X-irradiation on intracellular digestion by peritoneal phagocytes. Journal of Immunology 76, 192-199.

Emmerling, P., Finger, H. \& BockemüHL, J. (I975). Listeria monocytogenes infection in nude mice. Infection and Immunity 12, 437-439.

Fisher, S. (1966). Stimulation of splenic antigen uptake and of antibody response in mice by India ink or other blocking agents. Immunology Ir, I27-1 36 .

HAHN, H. (1974). Effects of dextran sulfate 500 on cell-mediated resistance to infection with Listeria monocytogenes in mice. Infection and Immunity ro, I 105-I 109.

KRAHENBUHL, J. L. \& REMINGTON, J. S. (I97I). In vitro induction of non-specific resistance in macrophages by specifically sensitized lymphocytes. Infection and Immunity 4, 337-343.

LANE, F. C. \& UNANUE, E. R. (I972). Requirement for thymus (T) lymphocytes for resistance to listeriosis. Journal of Experimental Medicine 135, I $104-1$ I 12.

Loor, F. \& Roelants, G. E. (I974). High frequency of T lineage lymphocytes in nude mouse spleen. Nature, London 25I, 229-230.

MACKANESS, G. B. (1964). The immunological basis of acquired resistance. Journal of Experimental Medicine I2I, I05-1 20.

Mackaness, G. B. (1969). The influence of immunologically committed lymphoid cells on macrophage activity in vivo. Journal of Experimental Medicine 129, 973-992.

MARRA, S. \& BALISH, E. (1974). Immunity to Candida albicans induced by Listeria monocytogenes. Infection and Immynity ro, 72-82.

McGregor, D. D., Hahn, H. H. \& Mackaness, G. B. (1973). The mediator of cellular immunity. V. Development of cellular resistance to infection in thymectomized irradiated rats. Cellular Immunology 6, 186-199.

Meltzer, M.S. (1976). Tumoricidal responses in vitro of peritoneal macrophages from conventionally housed and germ-free nude mice. Cellular Immunology 22, I76-r81.

Nelson, D. S. (1969). Macrophages and Immunity. Amsterdam: North-Holland Publishing Company.

NORTH, R. J. (1973a). Cellular mediators of anti-Listeria immunity as an enlarged population of short-lived, replicating $T$ cells. Kinetics of their production. Journal of Experimental Medicine 138, 342-355.

NORTH, R. J. (1973 b). Importance of thymus-derived lymphocytes in cell-mediated immunity to infection. Cellular Immunology 7, I66-I76.

Scheid, M. P., Goldstein, G. \& Boyse, E. A. (I975). Differentiation of T cells in nude mice. Science I90, I 2 I I-I 2 I 3.

Sher, N. A., Chaparas, S. D., Greenberg, L. E., Merchant, E. B. \& Vickers, J. H. (1975). Response of congenitally athymic (nude) mice to infection with Mycobacterium bovis (strain BCG). Journal of the National Cancer Institute 54, 1419-1426.

Takeya, K., Nomoto, K., Muraoka, S., Shimotori, S., Taniguchi, T. \& MiYake, T. (I977). Growth of two strains of Mycobacterium bovis (BCG) in athymic mice. Journal of General Microbiology roo, 403-405.

Zisman, B., Hirsch, M. S. \& Allinson, A. C. (I970). Selective effects of anti-macrophage serum, silica and anti-lymphocyte serum on phagocytosis on herpes virus infection of young adult mice. Journal of Immunology ro4, I 155 -I I 59. 